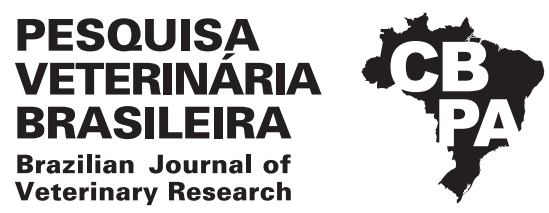

Pesq. Vet. Bras. 39(9):715-722, September 2019 DOI: 10.1590/1678-5150-PVB-5523

Original Article

ISSN 0100-736X (Print) Livestock Diseases

ISSN 1678-5150 (Online)

\title{
Bacterial identification, somatic cell count, antimicrobial profile and toxigenic Staphylococcus strains search from mastitic cow milk samples on small farms properties ${ }^{1}$
}

\author{
Ubirajara L. Lavor ${ }^{2}$, Felipe F. Guimarães ${ }^{2}$ (D), Anelise Salina² (D), \\ Mateus S.R. Mioni ${ }^{2}$ (D) and Helio Langoni ${ }^{2 *}$
}

\begin{abstract}
Lavor U.L., Guimarães F.F., Salina A., Mioni M.S.R. \& Langoni H. 2019. Bacterial identification, somatic cell count, antimicrobial profile and toxigenic Staphylococcus strains search from mastitic cow milk samples on small farms properties. Pesquisa Veterinária Brasileira 39(9):715-722. Departamento de Higiene Veterinária e Saúde Pública, Universidade Estadual Paulista, Rua Prof. Dr. Walter Maurício Correa s/n, Campus Botucatu, Botucatu, SP 18618-681, Brazil. E-mail: helio.langoni@unesp.br

Bovine mastitis has a negative impact on milk production and can pose risks to public health. The present study aimed to evaluate the quality of bovine milk from small farms in the Botucatu/SP region. Somatic cell counts (SCC), identification of pathogens involved in mastitis, and sensitivity antimicrobial profile of staphylococci isolated were performed. The presence of enterotoxin encoding genes in isolates of staphylococci obtained from milk was investigated. Milk samples from individual mammary quarters of cows were submitted to the California mastitis test (CMT) and SCC. Of the 239 dairy cows from 21 dairy herds evaluated (mean $=11.4$ animals/property), two cows $(0.8 \%)$ presented clinical mastitis and $86(35.9 \%)$ subclinical mastitis. Bacterial culture was performed in 177 quarter milk samples. Staphylococci were identified in 55 (31.1\%), corynebacteria in $45(25.4 \%)$, streptococci in $25(14.1 \%)$ and coliforms in four $(2.3 \%)$ milk samples. Average SCC from culture-positive samples was $1598 \times 10^{3}$ cells $/ \mathrm{mL}$, in case of staphylococci was $1362 \times 10^{3}$ cells $/ \mathrm{ml}$, streptococci was $2857 \times 10^{3}$ cells $/ \mathrm{mL}$, corynebacteria was $976 \times 10^{3}$ cells $/ \mathrm{mL}$ and in the cases of coliforms $1161 \times 10^{3}$ cells $/ \mathrm{mL}$ were obtained. Staphylococci showed a high sensitivity (>95\%) to cephalothin, cotrimoxazole, enrofloxacin, and gentamicin, with a $41.2 \%$ resistance to penicillin and $11.8 \%$ to oxacillin. Both coagulase positive (CPS) and negative staphylococci (CNS) carried genes encoding enterotoxins in $21.6 \%$ of the first group and $41.9 \%$ in the second. The sea gene was the most detected $45.8 \%(n=24)$ between them, followed by seb with $29.2 \%$ and sec with $25.0 \%$. The sed gene was not identified. We highlight the potential risk to public health in the possibility of strains of Staphylococcus spp. enterotoxin-producing genes that can cause staphylococcal food poisoning.
\end{abstract}

INDEX TERMS: Bacterial identification, somatic cell count, antimicrobial profile, toxigenic, Staphylococcus, mastitis, cow, milk, farms, enterotoxins, public health, gene, sea, seb, sec.

RESUMO.- [Identificação bacteriana, contagem de células somáticas, perfil antimicrobiano e pesquisa de linhagens toxigênicas de Staphylococcus em amostras de leite bovino

\footnotetext{
${ }^{1}$ Received on February 27, 2019.

Accepted for publication on April 4, 2019.

${ }^{2}$ Departamento de Higiene Veterinária e Saúde Pública, Universidade Estadual Paulista (Unesp), Rua Prof. Dr. Walter Maurício Correa s/n, Campus Botucatu, Botucatu, SP 18618-681, Brazil. *Corresponding author: helio.langoni@unesp.br
}

de pequenas propriedades rurais.] A mastite bovina impacta negativamente a produção leiteira e pode acarretar riscos à saúde pública. 0 presente estudo teve como objetivo a avaliação da qualidade do leite bovino proveniente de pequenas propriedades na região de Botucatu/SP. Foi realizada a contagem de células somáticas (CCS), identificação dos patógenos envolvidos nas mastites, e realizado o perfil de sensibilidade aos antimicrobianos dos estafilococos isolados. Pesquisou-se a presença de genes codificadores de enterotoxinas em isolados de estafilococos obtidos a partir do leite mastítico. 
Amostras de leite de quartos mamários individuais de vacas foram submetidas ao "California mastitis test" (CMT) e à CCS. Das 239 vacas em lactação provenientes de 21 rebanhos leiteiros avaliados (média $=11,4$ animais/propriedade), dois $(0,8 \%)$ animais apresentaram mastite clínica e, 86 (35,9\%) mastite subclínica. 177 amostras de leite foram cultivadas em ágar sangue bovino 5\% e ágar MacConckey e obteve-se 55 (31,1\%) Staphylococcus spp., 25 (14,1\%) Streptococcus spp., 45 (25,4\%) Corynebacterium spp. e quatro (2,3\%) coliformes. A média da CCS das amostras procedentes de todos os quartos mamários infectados avaliados foi de $1598 \times 10^{3}$ células/mL, enquanto que nos casos que foram isolados Staphylococcus spp. foi de $1362 \times 10^{3}$ células/mL, Streptococcus spp. $2857 \times 10^{3}$ células $/ \mathrm{mL}$, Corynebacterium spp. de $976 \times 10^{3}$ células $/ \mathrm{mL}$ e nos casos de coliformes $1161 \times 10^{3}$ células $/ \mathrm{mL}$. Os estafilococos revelaram grande sensibilidade ( $>95 \%)$ à cefalotina, cotrimoxazol, enrofloxacina e gentamicina, com resistência de $41,2 \%$ à penicilina e 11,8\% à oxacilina. Tanto estafilococos coagulase positivos (ECP) como negativos (ECN) revelaram genes codificadores de enterotoxinas em $21,6 \%$ do primeiro grupo e $41,9 \%$ no segundo. 0 gene sea foi o mais detectado $45,8 \%$ $(n=24)$, seguido pelo seb com $29,2 \%$ e sec com $25,0 \%$. 0 gene codificador da sed não foi identificado. Frente aos resultados, destaca-se o risco potencial à saúde pública pela possibilidade de veiculação de linhagens de Staphylococcus spp. carreadores de genes produtores de enterotoxinas, podendo ocasionar toxi-infecções alimentares.

TERMOS DE INDEXAÇÃO: Identificação bacteriana, contagem de células somáticas, Staphylococcus, leite, bovinos, propriedades rurais, mastite, enterotoxinas, saúde pública, genes, sea, seb, sec.

\section{INTRODUCTION}

Approximately $85 \%$ of the 1.3 million dairy farmers in Brazil can be classified as small producers. Low technification, poor management, poor sanitary control and inadequate hygiene conditions decrease the quality of the raw milk produced, posing a risk to consumers of the transmission of micro-organisms that cause zoonoses or possible toxi-infections.

Mastitis, the most prevalent disease in dairy cattle, affects the mammary gland leading to physicochemical and bacteriological changes in milk. Infectious causes are the most significant, both economically and in the public health interest. SCC is considered a good indicator of mammary gland health because it assesses the number of inflammatory cells present in milk. At counts above 200,000 cells/mL, fourth breasts are considered positive for mastitis (Dohoo \& Leslie 1991).

Determining the etiology of mastitis enables the adoption of appropriate antimicrobial treatment. The differentiation of the contagious or environmental factors of the infection, the adoption of disease prevention and control measures are distinct for each group of microorganisms (Langoni et al. 1998, Radostits et al. 2007).

Despite the recent regulation of the dairy chain has led to transformations in the sector, such as the way of collection, with the bulk collection and the end of receiving uncooled milk, beginning of payment policies for quality, incorporation of technologies in the field and development of new products and industrial processes, the difficulties faced by small farmers in adapting their production to the new quality parameters established are still big (Carvalho 2010).
Due to the impossibility of meeting the pressures imposed by the market or lack of motivation due to the little consolidation of public policies in the dairy sector, many producers end up joining the informal market. Risking illegality, this producer can add to his production part of the income that would be appropriated by the intermediaries. (Silva \& Tsukamoto 2001). As a result, this informally traded milk exposes consumers to greater risks, with serious public health implications.

Hygienic obtaining of milk, in addition to directly impacting product quality, increases the productivity of the herd by decreasing the prevalence of intramammary infections, resulting in direct and indirect economic gains for farmers (Langoni et al. 2011).

Staphylococcus is one of the main agents involved in the prevalence and persistence of mastitis in the dairy herd. (Fagundes \& Oliveira 2004, Piepers et al. 2007). Staphylococcus aureus stands out for its difficult control due to its high resistance to the antimicrobial treatments used and the various virulence factors, causing long-lasting infections with low cure rates (Silva et al. 2014, Guimarães et al. 2017). Another important feature is the ability to produce enterotoxins, which can lead to poisoning by ingestion of thermostable toxins (Pinchuk et al. 2010 ) produced and released during their multiplication in food (Soriano et al. 2002).

Staphylococcal enterotoxins (SE) are a group of low molecular weight single chain proteins produced during all stages of bacterial multiplication, but especially during the half and end of the exponential phase (Soriano et al. 2002). Classic enterotoxins (A, B, C, and D) are the most common in bovine mastitis milk isolates. Their production is not restricted to Staphylococcus aureus species, but also to other staphylococci species such as coagulase negative staphylococci (CNS) (Radostits et al. 2007, Freitas Guimarães et al. 2013). The importance of the genus and its toxins is well elucidated in the literature, however, there is little information on the occurrence of genes that encode these toxins in the milk of animals from small dairy herds.

In order to reduce intramammary infections, it is essential to develop orientation and support activities for producers, such as extension activities, lectures and training directed to them. In order to achieve this reduction, it is recommended to improve the diagnostic techniques of clinical and subclinical mastitis, laboratory identification of the infectious agents involved, appropriate antimicrobial treatment of the affected quarters, cleaning and disinfection of the teats (pre and post-dipping) as well as the environment, in addition to the provision of good quality water to ensure the proper development of the inherent production activities.

This study aimed to investigate the aerobic microbiota of subclinical mastitis cases observed in small dairy properties, the relationship between the isolated species and the milk SCC of the respective breast quarters positive for the CMT test. It also aimed to identify the etiology of mastitis, as well as the potential risks to public health by detecting enterotoxin coding genes in strains of Staphylococcus spp. and established the antimicrobial sensitivity profile of staphylococci isolates obtained.

\section{MATERIALS AND METHODS}

Microbiological analyses, somatic cell count and molecular studies were performed at the Mastitis Research Center (NUPEMAS) of the Department of Veterinary Hygiene and Public Health, School of Veterinary Medicine and Animal Science, Unesp, Botucatu Campus/SP. 
Dairy properties. The study was conducted in dairy herds whose daily production was less than 100 liters of milk. There were 21 distinct herds located in the rural area of Botucatu/SP. The number of lactating cows per herd ranged from 3 to 20 , predominantly crossbred animals.

Mastitis diagnosis and sample collection. We screened all lactating cows from each herd. The diagnosis of clinical mastitis was based on clinical signs of breast inflammation (pain, flushing, heat and swelling) and/or changes in milk macroscopy (lumps, pus, blood or filaments) by proof of dark-bottomed cup or Tamis (Radostits et al. 2007). Subclinical mastitis was diagnosed with the aid of CMT (Schalm \& Noorlander 1957). Tamis-positive milk samples with a CMT positivity score were collected aseptically, according to pre-established procedures (NMC 1999). Until microbiological examinations are performed immediately upon arrival at the laboratory, the samples were kept refrigerated $\left(4\right.$ to $\left.8^{\circ} \mathrm{C}\right)$ in isothermal boxes with recyclable ice.

Microbiological culture. The microbiological culture was performed according to standard procedures (NMC 1999). Initially, 10 microliters of each milk sample were grown in $5 \%$ bovine blood agar and MacConkey agar media, incubating at $37^{\circ} \mathrm{C}$, observing microbial development every 24 hours for three days. The isolated colonies were picked in BHI (brain heart infusion) broth, studied morphologically for phenotypic characteristics (pigmentation and hemolysis), as well as morphologically by the Gram technique, and classified according to their ability to synthesize the coagulase enzyme in order to differentiate coagulase positive (CPS) from negative staphylococci (CNS). We used other biochemical tests to complement the classification of the other species and subspecies of CNS, such as the fermentation of sugars: mannitol, maltose, trehalose, xylose, arabinose, sucrose, lactose, xylitol, ribose and fructose. We observed urease and/or ornithine decarboxylase production, nitrate reduction and susceptibility to novobiocin (Cunha et al. 2007). For identification of enterobacteria, colonies isolated from MacConkey were subjected to biochemical tests of EPM, MILi and Simmons Citrate, where the production of gas, glucose, enzyme L-tryptophan deaminase (LTD), H2S, urea, motility, indole and lysine were evaluated (Trabulsi et al. 1999). Colonies suggestive of streptococci were submitted to catalase test, esculin hydrolysis and CAMP test, aiming to differentiate Streptococcus agalactiae from other species of mastitis-causing streptococci (Quinn et al. 2005).

Animals' SCC. In parallel to the above procedure, they were collected in a plastic bottle containing bronopol cell preservative (Bertrand 1996), Tamis or CMT-positive breast milk samples. SCC was performed on Somacount $300^{\circledR}$ equipment (Bentley, UK) by flow cytometry.

Microbial Sensitivity Profile. Staphylococcus spp. isolates were tested for microbial sensitivity by the disk diffusion method recommended by Bauer et al. (1966), on plates containing Mueller Hinton agar, arranged with the following antimicrobials: neomycin $(30 \mu \mathrm{g})$, gentamicin $(10 \mu \mathrm{g})$, penicillin $(10 \mathrm{UI})$, oxacillin $(10 \mu \mathrm{g})$, cephalothin $(30 \mu \mathrm{g})$, enrofloxacin $(5 \mu \mathrm{g})$ and cotrimoxazole $(25 \mu \mathrm{g})$. Interpretation of inhibition halos followed the Clinical and Laboratory Standards Institute (CLSI 2005) reference.

DNA extraction. Staphylococcus spp. were cultured in BHI broth, concentrated by centrifugation and DNA extracted using the Illustra Blood Genomic Prep Mini Spin Kit (GE Healthcare), as recommended by the manufacturer, after initial cell digestion with lysozyme $(10 \mathrm{mg} / \mathrm{mL})$ and Proteinase $\mathrm{K}(20 \mathrm{mg} / \mathrm{mL})$.

Detection of enterotoxin coding genes. We used specific primers for the EEA (sea), EEB (seb), EEC (sec) and EED (sed) enterotoxin coding genes, according to Johnson et al. (1991). Reactions were performed in $0.2 \mathrm{~mL}$ microtubes in a total volume of $25 \mu \mathrm{L}$, with $10 \mathrm{pmol}$ of each primer, 1.0U Taq Platinum DNA polymerase (Invitrogen ${ }^{\circledR}$ ), $200 \mu \mathrm{M}$ triphosphate deoxyribonucleotides, 1 X PCR buffer, $0.75 \mathrm{mM}$ of $\mathrm{MgCl} 2$ and $3 \mu \mathrm{L}$ of sample. In all reactions negative controls were used with the replacement of nucleic acid by water. Incubation was performed on the Mastercycler gradient thermocycler (Eppendorf ${ }^{\circledR}$ ).

Visualization of amplified products. Agarose gels were prepared in $2.0 \%$ concentration in $1 \mathrm{X}$ TBE buffer, stained with $1.0 \mu \mathrm{L} / \mathrm{mL}$ SYBR Safe DNA gel stain (Invitrogen ${ }^{\circledR}$ ). Products size were compared to the $100 \mathrm{bp}$ standard and subsequently photographed under UV transillumination.

Statistical analysis. The results were analyzed by general descriptive statistics, using the Windows Excel ${ }^{\circledR}$ program. Mixed linear models were used to compare the mean milk SCC between mammary glands infected with different pathogens. We used logistic regression models or Chi-square tests to test the association between Staphylococcus spp. and the antimicrobial sensitivity profile.

\section{RESULTS AND DISCUSSION}

\section{Mastitis etiology}

The results obtained for isolated species in the microbiological culture of 177 lactating cow's milk samples showed the occurrence of important mastitis pathogens and are presented in Table 1. The predominance of the genus Staphylococcus agrees with other prevalence studies conducted in both Brazilian dairy herds and in dairy farms in other countries (Nader Filho et al. 2007, Bolaños et al. 2014).

Corynebacterium spp. also plays an important role in the etiology of mastitis. C. bovis is responsible for significant reduction in milk production of infected fourth breasts. When evaluating the presence of $C$. bovis in dairy herds, Domingues et al. (1998) observed a decrease in milk production of up to $27.6 \%$, while Zafalon et al. (1999) reported a $30.9 \%$ drop, in addition to observing a significant increase in milk SCC in animals with these bacteria.

Of the 31 isolates classified as Streptococcus, $67.7 \%(\mathrm{n}=21)$ of these were classified as $S$. agalactiae, $25.8 \%(\mathrm{n}=8)$ as S. dysgalactiae and $6.5 \%(\mathrm{n}=2)$ as $S$. bovis. The main contagious agent of the genus Streptocococcus and frequently isolated in the etiology of bovine mastitis is $S$. agalactiae. It is a mandatory and highly contagious intramammary microorganism (González et al. 1986) and can be efficiently eliminated with intramammary treatments during the lactation period.

Table 1. Bacterial isolation in milk samples from cows with clinical and subclinical mastitis in small dairy farms

\begin{tabular}{lcc}
\hline \multicolumn{1}{c}{ Bacterial genus } & Total (N) & Total \% \\
\hline Staphylococcus spp. & 55 & 31.1 \\
Corynebacterium spp. & 45 & 25.4 \\
No growth/contaminated* & 34 & 19.2 \\
Streptococcus spp. & 25 & 14.1 \\
Corynebacterium spp./Staphylococcus spp. & 8 & 4.5 \\
Staphylococcus spp./Streptococcus spp.** & 5 & 2.8 \\
Coliforms & 4 & 2.3 \\
Corynebacterium spp./Streptococcus spp.** & 1 & 0.6 \\
TOTAL & 177 & 100
\end{tabular}

*No growth/contaminated $=$ no bacterial growth samples or growth of three or more different microorganisms (NMC 1999). 
Coliforms are important indicators of the hygienic and sanitary quality of food and frequently participate in breast infections. In the present study, only $2.3 \%(n=4)$ of the samples were found. Freitas Guimarães et al. (2013) and Ribeiro et al. (2009) also reported prevalence of Enterobacteriaceae-related mastitis in dairy cows.

The high prevalence of contagious microorganisms of the genera Staphylococcus, Streptococcus and Corynebacterium is due to the habitat of this group consisting of the mucosa and skin of the animals, indicating problems related to the operational hygiene of milking and possible chronicity of breast infection.

Regarding the biochemical characterization of staphylococci (Table 1), the main isolated species was $S$. aureus $(\mathrm{n}=21)$. We also observed the participation of CNS as important pathogens in bovine mastitis, as reported by Piepers et al. (2007).

Staphylococcus aureus and S. intermedius are causative agents of bovine mastitis, the latter being less frequently isolated in milk samples (Roberson et al. 1996, Oliveira et al. 2011, Freitas Guimarães et al. 2013). These species may be responsible for the occurrence of food poisoning outbreaks when associated with the presence of enterotoxin coding genes (Radostits et al. 2007, De Freitas Guimarães et al. 2013, Rall et al. 2014). S. hyicus is appointed as responsible for the production of exotoxin from scalded skin syndrome in pigs (Tanabe et al. 1996). Chenier \& Lallier (2012) also attributed to this species some infections in laying hens. In this sense, the presence of other animals, such as swine and poultry on small dairy farms, may have contributed to the participation of this genus in the observed mastitis.

Regarding the species of CNS, the present study agreed with the scientific literature that indicated frequent participation of $S$. hominis and, to a lower frequency of S. sciuri, S. capitis (Radostits et al. 2007). S. epidermidis is more prevalent and persistent in human skin and mucous membranes. It can be inferred that its prevalence may be directly related to precariousness in the milking procedures in the visited properties, being necessary the confirmation from the bacteriological swab examination of the hands of the milkers.

\section{Somatic cell count}

Milk SCC reflects the intensity of the inflammatory response to breast tissue infection, and the values obtained in the present study are presented in Table 2. Defense cells, mainly neutrophils, migrate into the udder to eliminate the pathogen. In addition to the genetic characteristics and immunological capacity of animals, SCC is directly influenced by lactation period, month and season, order of birth, among others. However, the specific effect of pathogens and the state of breast infection are the main factors responsible for their variations.

The major pathogens (S. aureus, S. agalactiae and coliforms) cause mastitis, which results in large variations in milk composition and SCC, while secondary pathogens (CNS and C. bovis) cause moderate inflammatory process (Harmon 1994). The results obtained in this study corroborate those found by Souza et al. (2009) in which $S$. agalactiae was responsible for the largest increase in dairy cow SCC.

Comparison between the SCC values obtained within the Staphylococcus genus for the CPS and CNS groups revealed that the mean value of the first group $\left(1632 \times 10^{3}\right.$ cells $\left./ \mathrm{mL}\right)$ was significantly higher than the average observed in cases of CNS $\left(1060 \times 10^{3}\right.$ cells $\left./ \mathrm{mL}\right)$. However, the comparison of the observed maximum values, $7139 \times 10^{3} \mathrm{CS} / \mathrm{mL}$ for CPS and $7357 \times 10^{3} \mathrm{CS} / \mathrm{mL}$ for CNS, demonstrates the ability of the latter to elicit high intensity inflammatory processes.

\section{Antimicrobial resistance}

The genus Staphylococcus showed high sensitivity to most antimicrobials. Cephalothin, cotrimoxazole, enrofloxacin and gentamicin were the most effective antimicrobials (>95.0\%). However, we noted worrying indexes of intermediate sensitivity or complete resistance, compared to some drugs, especially penicillin (41.2\%), oxacillin (11.8\%) and neomycin (5.8\%) (Table 3).

Bacterial resistance is related to the existence of genes capable of encoding different biochemical mechanisms that give the microorganism the ability to resist the action of various drugs. It is the result of selective pressure on pathogens that occurs through the use or not of medicines (Tavares 2000).

Table 2. CPS and CNS strains isolated from milk of cows with mastitis in small dairy farms

\begin{tabular}{|c|c|c|c|c|c|}
\hline Group & Species & $\mathrm{N}$ & $\%$ in the group & $\%$ in the genus & $\%$ in the isolates \\
\hline \multirow{4}{*}{ CPS } & Staphylococcus spp. & 9 & 24.3 & 13.2 & 6.3 \\
\hline & S. aureus & 21 & 56.8 & 30.9 & 14.7 \\
\hline & S. hyicus* & 4 & 10.8 & 5.9 & 2.8 \\
\hline & S. intermedius & 2 & 5.4 & 2.9 & 1.4 \\
\hline \multirow{10}{*}{ CNS } & S. schleiferi & 1 & 2.7 & 1.5 & 0.7 \\
\hline & Subtotal & 37 & 100.0 & 54.4 & 25.9 \\
\hline & Staphylococcus spp. & 8 & 25.8 & 11.8 & 5.6 \\
\hline & S. xylosus & 9 & 29.0 & 13.2 & 6.3 \\
\hline & S. epidermidis & 6 & 19.4 & 8.8 & 4.2 \\
\hline & S. chromogenes & 5 & 16.1 & 7.4 & 3.5 \\
\hline & S. warneri & 2 & 6.5 & 2.9 & 1.4 \\
\hline & S. simulans & 1 & 3.2 & 1.5 & 0.7 \\
\hline & Subtotal & 31 & 100.0 & 45.6 & 21.7 \\
\hline & TOTAL & 68 & - & 100.0 & 47.6 \\
\hline
\end{tabular}

*S. hyicus isolates obtained in this study were grouped together with other CPS for positive coagulase test results. 
In addition to being a serious animal and public health problem, antimicrobial resistance results in direct financial losses to dairy farmers due to drug costs and milk disposal during treatment. They also lose dairy products and end consumers. When the recommended grace periods for antimastitics are not respected, the quality and safety of dairy products are compromised.

In a large study conducted in the state of Minas Gerais, Costa et al. (2013) evaluated the antimicrobial profile of 352 isolates of Staphylococcus aureus obtained from 35 different dairy properties. Resistance percentages obtained for cephalothin $(0.28 \%)$, gentamicin $(1.69 \%)$, neomycin $(3.35 \%)$, enrofloxacin $(<1.0 \%)$ and penicillin $(34.1 \%)$ were very similar to our results.

Regarding penicillin, the staphylococcal strains isolated in the present study showed a sensitivity percentage of $58.8 \%$ $(n=40)$ of isolates sensitive to this antimicrobial, $39,7 \%$ $(\mathrm{n}=27)$ of the isolates resulted in intermediate antimicrobial sensitivity and $1.5 \%(n=1)$ was resistant. In small dairy herds, low technification and probable deficiencies in therapeutic protocols could result in higher levels of microorganism resistance to penicillin, widespread antimicrobial agent in the treatment of mastitis in dairy herds (Vintov et al. 2003, Rabello et al. 2005). Contrary to what would be expected in isolates obtained from this type of herd, only one isolate resistant to the drug in question was observed.

Regarding oxacillin, the total $11.8 \%$ of intermediate sensitivity and resistance observed is like those obtained by Siqueira (2011) in bacteria of this genus isolated from samples of organic milk in the Botucatu region, in which $88 \%$ were sensitive to the drug.

The indiscriminate use of penicillin reported by the producers of this study may have contributed to the selective pressure of strains resistant to this antimicrobial, as compared the profiles obtained for groups of CPS and CNS. In the first,
$48.6 \%$ of the isolates were considered sensitive and $51.4 \%$ were resistant to the drug, while the microorganisms of the CNS group presented $71.0 \%$ sensitivity and $25.8 \%$ resistance. The fact that CPS induces a more intense inflammatory response in cases of mastitis tends to use antimastitic treatments more frequently than CNS, and may lead to selective pressure and consequent resistance of microorganisms to the drug.

\section{Enterotoxins}

Of the 68 samples subjected to enterotoxin-encoding gene screening $30.9 \%(n=21)$ were positive for at least one type of classical enterotoxin encoding gene (sea, seb, sec or sed). The frequency of the CPS and CNS species, and the association with the genes are presented in Table 4.

Of the 37 CPS samples submitted to PCR, 21.6\% $(n=8)$ were positive for at least one of the classic enterotoxin coding genes and of the 31 CNS samples, the positivity was 41.9\% (n=13). De Freitas Guimarães et al. (2013) obtained a significantly higher positivity of the CNS in relation to the CNS in the research of the same genes.

Considering only samples positive for the detection of enterotoxin coding genes, it was verified that the gene sea was the most prevalent with $45.8 \%$, followed by seb with $29.2 \%$ and sec with $25 \%$ frequency. The sed gene was not detected in any of the samples. These results partially agree with those found in the scientific literature. Zoli et al. (2002) pointed out that sed-expressed enterotoxin is the second main type involved in food outbreaks, with bone poisoning being more frequent. Pinchuk et al. (2010) also associated food poisoning with sed detection.

The study by Pimentel et al. (2002) in composite milk samples revealed the production of some type of enterotoxin in $24.6 \%$ of CPS samples and $41.3 \%$ of CNS samples. The authors concluded that coagulase negative species produce enterotoxins more frequently, highlighting the lack of updated Brazilian

Table 3. Average SCC of milk from fourth breasts of subclinical mastitis cows according to bacterial genus

\begin{tabular}{lccccccc}
\hline \multicolumn{1}{c}{ SCCx $10^{3}(\mathrm{CS} / \mathrm{mL})$} & STA & STR & COR & COLIF. & STA/STR & COR/STA & COR/STR \\
\hline Average & 1362 & 2857 & 976 & 1161 & 3707 & 1904 & - \\
Mean & 579 & 1456 & 501 & 465 & 4501 & 934 \\
Maximum & 7357 & 9999 & 6554 & 3369 & 9999 & 4655 \\
Minimum & 124 & 175 & 42 & 319 & 375 & 508 & - \\
N & 55 & 25 & 45 & 4 & 5 & - & 8 \\
$\%$ & 38.5 & 17.5 & 31.5 & 2.8 & 3.5 & 5.6
\end{tabular}

STA = Staphylococcus spp., SRT = Streptcoccus spp., COR = Corynebacterium spp., COLIF. = coliform groups, STA/STR = genus Staphylococcus spp. and Streptococcus spp., COR/STA = genus Corynebacterium spp. and Staphylococcus spp., COR/STR = genus Corynebacterium spp. and Streptococcus spp.

Table 4. Sensitivity profile of Staphyloccocus spp. against different antimicrobials

\begin{tabular}{|c|c|c|c|c|c|c|}
\hline \multirow{3}{*}{ Antimicrobial } & \multicolumn{6}{|c|}{ Staphylococcus spp. } \\
\hline & \multicolumn{2}{|c|}{ Sensitive } & \multicolumn{2}{|c|}{ Intermediate } & \multicolumn{2}{|c|}{ Resistant } \\
\hline & $\mathrm{N}$ & $\%$ & $\mathrm{~N}$ & $\%$ & $\mathrm{~N}$ & $\%$ \\
\hline Cephalothin $(30 \mu \mathrm{g})$ & 67 & 98.5 & 1 & 1.5 & 0 & 0.0 \\
\hline Cotrimoxazole $(25 \mu \mathrm{g})$ & 66 & 97.1 & 1 & 1.5 & 1 & 1.5 \\
\hline Enrofloxacin $(\mu \mathrm{g})$ & 65 & 95.6 & 1 & 1.5 & 2 & 2.9 \\
\hline Gentamycin $(10 \mu \mathrm{g})$ & 66 & 97.1 & 2 & 2.9 & 0 & 0.0 \\
\hline Neomycin $(30 \mu \mathrm{g})$ & 64 & 94.1 & 2 & 2.9 & 2 & 2.9 \\
\hline Oxacilin $(10 \mu \mathrm{g})$ & 60 & 88.2 & 5 & 7.4 & 3 & 4.4 \\
\hline Penicilin (10UI) & 40 & 58.8 & 27 & 39.7 & 1 & 1.5 \\
\hline
\end{tabular}


Table 5. Frequency of enterotoxin coding genes in CPS and CNS isolated from milk samples from small dairy farms

\begin{tabular}{|c|c|c|c|c|c|c|}
\hline \multirow{2}{*}{ CPS } & \multicolumn{2}{|c|}{ Samples results } & \multicolumn{4}{|c|}{ Genes } \\
\hline & Negatives & Positives & sea & seb & $\mathrm{sec}$ & sed \\
\hline Staphylococcus spp. & 8 & 1 & 1 & - & - & - \\
\hline S. aureus & 17 & 4 & 3 & - & 2 & - \\
\hline S. hyicus & 2 & 2 & 1 & 1 & - & - \\
\hline S. schleiferi & - & 1 & - & - & 1 & - \\
\hline S. intermedius & 2 & - & - & - & - & - \\
\hline Subtotal & 29 & 8 & 5 & 1 & 3 & 0 \\
\hline CNS & Negatives & Positives & sea & seb & $\sec$ & sed \\
\hline Staphylococcus spp. & 4 & 4 & 2 & 2 & 1 & - \\
\hline S. chromogenes & 2 & 3 & - & 2 & 1 & - \\
\hline S. xylosus & 6 & 3 & 1 & 2 & - & - \\
\hline S. epidermidis & 4 & 2 & 2 & - & 1 & - \\
\hline S. warneri & 1 & 1 & 1 & - & - & - \\
\hline S. simulans & 1 & - & - & - & - & - \\
\hline Subtotal & 18 & 13 & 6 & 6 & 3 & 0 \\
\hline
\end{tabular}

legislation (RDC no. 12/2001 of the National Health Surveillance Agency, Anvisa) that advocates for only CPS counting for risk assessment of enterotoxin production (Brasil 2001).

Nevertheless, as reported by Faccioli (2010), a high prevalence of enterotoxin coding genes does not necessarily correspond to high enterotoxin expression. Carmo et al. (2009) evidenced the presence of natural mechanisms capable of inhibiting enterotoxin production in milk contaminated with enterotoxigenic $S$. aureus strains. Factors such as bacterial growth conditions, presence of glucose, $\mathrm{pH}$ of the medium and even regulatory systems of the microorganism itself interfere with gene expression (Cunha et al. 2007).

The results in Table 5 showed that in both CPS and CNS strains, there are isolates that have genes encoding two types of staphylococcal enterotoxins. In $S$. aureus strains, the presence of two enterotoxin coding genes, sea and sec. In the CNS strains, S. epidermidis revealed the sea gene in association with sec. Another isolate from Staphylococcus spp. presented the $s e b$ and sec genes, reinforcing that it is possible that certain staph strains express concomitantly more than one enterotoxin-producing gene.

We showed the importance of milk in the circulation of staphylococcal strains with enterotoxigenic potential that may, under favorable conditions, lead to food poisoning. In the context of family farming, this potential risk is even more worrisome because milk and dairy products are ingested by producers and their families, in addition to the clandestine trade in milk.

\section{CONCLUSIONS}

The results of the present study revealed that there is great variability in the etiology of mastitis in dairy herds of small rural properties.

The high frequency of isolation of contagious species of the Staphylococcus spp., Streptococcus spp. and Corynebacterium spp. in the milk of the animals evidences the greater importance of contagious mastitis in the herds evaluated. SCC showed significantly different values according to the pathogen responsible for inflammation of the mammary gland.
In the antimicrobial sensitivity profile, the CPS presented higher resistance when compared to the CNS. The presence of enterotoxin coding genes A, B and C in Staphylococcus spp. demonstrated the potential risks to public health due to the possibility of food poisoning through the consumption of raw milk from this type of herd.

The multiple etiology of mastitis observed in the small dairy farms analyzed in the study reinforces the importance of microbiological evaluation before the adoption of milk quality control and monitoring programs. Therefore, we emphasize the importance of the implementation of indirect diagnostic tests, such as CMT or SCC, for the detection of subclinical mastitis for subsequent microbiological examination and success in control programs.

Conflict of interest statement.- The authors have no competing interests.

\section{REFERENCES}

Bauer A.W., Kirby W.M.M., Sherris J.C. \& Turck M. 1966. Antibiotic susceptibility testing by a standardized single disk method. Am. J. Clin. Pathol. 45(4):493496. <http://dx.doi.org/10.1093/ajcp/45.4_ts.493> <PMid:5325707>

Bertrand J.A. 1996. Influence of shipping container preservative and breed on analysis of milk components of shipped samples. J. Dairy Sci. 6(1):145148. <http://dx.doi.org/10.3168/jds.S0022-0302(96)76346-4>

Bolaños C.A.D., Pantoja J.C.F., Alves A.C., Risseti R.M., Listoni F.J.P. \& Ribeiro M.G. 2014. Qualidade do leite de vacas criadas no sistema silvopastoril no Vale do Cauca, Colômbia. Pesq. Vet. Bras. 34(2):134-140. <http://dx.doi. org/10.1590/S0100-736X2014000200007>

Brasil 2001. Aprova regulamento técnico sobre padrões microbiológicos em alimentos. Resolução RDC no 12, de 2 de janeiro de 2001, Agência Nacional de Vigilância Sanitária, Ministério da Saúde, Brasília. 18p.

Carmo L.S., Guedes L.G., Bambirra L.H.S., Cerqueira M.M.O.P. \& Nicoli J.R. 2009. Produção de enterotoxina SEA e SEB em leite contaminado com as linhagens (FRI 722 e FRI S-6) produtoras respectivamente de enterotoxina SEA e SEB e uma linhagem de Lactobacillus. Revta Fund. Ezequiel Dias, Gestão Ciênc. Saúde 4(1):105-110.

Carvalho G.R. 2010. A indústria de laticínios no Brasil: passado, presente e futuro. Circular Técnica 102, Embrapa Gado de Leite, Juiz de Fora, MG. 12p. 
Chénier S. \& Lallier L. 2012. Acantholytic folliculitis em epidermitis associated with Staphylococcus hyicus in a line of white leghorn laying chickens. Vet. Pathol. 49(2):284-287.<http://dx.doi.org/10.1177/0300985811415705> $<$ PMid:21856871>

CLSI 2005. Performance standards for antimicrobial susceptibility testing. CLSI approved standard M100-S15, Clinical and Laboratory Standards Institute, Wayne, PA.

Costa M.C., Barros R.A., Custódio D.A.C., Pereira U.P., Figueiredo D.J. \& Silva D. 2013. Resistência a antimicrobianos em Staphyloccocus aureus isolados em mastite em bovinos leiteiros de Minas Gerais, Brasil. Arqs Inst. Biológico, São Paulo, 80(3):297-302.

Cunha M.L.R.S., Peresi E., Calsolari R.A.O. \& Araújo Júnior J.P. 2007. Detection of enterotoxins and toxic shock syndrome toxin-1 genes in Staphylococcus with emphasis in coagulase-negative staphylococci. Microbiol. Immun. 51(4):381-390. <http://dx.doi.org/10.1111/j.1348-0421.2007.tb03925.x>

Dohoo I.R. \& Leslie K.E. 1991. Evaluation of changes in somatic cell counts as indicators of new intramammary infections. Prev. Vet. Med. 10(3):225-237. <http://dx.doi.org/10.1016/0167-5877(91)90006-N>

Domingues P.F., Langoni H. \& Padovani C.R. 1998. Influência da mastite subclínica sob a produção de leite. Vet. Zootec. 10:99-106.

Faccioli P.Y. 2010. Detecção molecular de Staphylococcus aureus e de suas toxinas no leite de tanque de rebanhos bovinos, em condições de refrigeração e sob temperatura ambiente. Doctoral Dissertation, Faculdade de Medicina Veterinária e Zootecnia, Universidade Estadual Paulista, Botucatu, SP. 134p.

Fagundes H. \& Oliveira C.A.F. 2004. Infecções intramamárias causadas por Staphylococcus aureus e suas implicações em paúde pública. Ciência Rural 34(4):1315-1320. <http://dx.doi.org/10.1590/S0103-84782004000400058>

Freitas Guimarães F.F., Nóbrega D.B., Richini-Pereira V.B., Marson P.M., Figueiredo Pantoja J.C. \& Langoni H. 2013. Enterotoxin genes in coagulasenegative and coagulase-positive staphylococci isolated from bovine milk. J. Dairy Sci. 96(5):2866-2872.<http://dx.doi.org/10.3168/jds.2012-5864> $<$ PMid:23477822>

González R.N., Jasper D.E., Bushnell R.B. \& Farver T.B. 1986. Relationship between mastitis pathogen numbers in bulk tank milk and bovine udder infections in California dairy herds. J. Am. Vet. Med. Assoc. 189(4):442445. <PMid:3531123>

Guimarães F.F., Manzi M.P., Joaquim S.F., Richini-Pereira V.B. \& Langoni H. 2017. Short communication: Outbreak of methicillin-resistant Staphylococcus aureus (MRSA)-associated mastitis in a closed dairy herd. J. Dairy Sci. 100(1):726730. <http://dx.doi.org/10.3168/jds.2016-11700><PMid:27837983>

Harmon R.J. 1994. Physiology of mastitis and factors affecting somatic cell counts. J. Dairy Sci. 77(7):2103-2113. <http://dx.doi.org/10.3168/jds. S0022-0302(94)77153-8><PMid:7929968>

Johnson W.M., Tyler S.D., Ewan E.P., Ashton F.E., Pollard D.R. \& Rozee K.R. 1991. Detection of genes for enterotoxins, exfoliative toxins, and toxic shock syndrome toxin 1 in Staphylococcus aureus by the polymerase chain reaction. J. Clin. Microbiol. 29(3):426-430. <PMid:2037659>

Langoni H., Silva A.V., Cabral K.G. \& Domingues P.F. 1998. Aspectos etiológicos na mastite bovina: flora bacteriana aeróbica. Revta Bras. Med. Vet. 20(5):204-209.

Langoni H., Penachio D.S., Citadella J.C.C., Laurino F., Faccioli-Martins P.Y., Lucheis S.B., Menozzi B.D. \& Silva A.V. 2011. Aspectos microbiológicos e de qualidade do leite bovino. Pesq. Vet. Bras. 31(12):1059-1065. <http:// dx.doi.org/10.1590/S0100-736X2011001200004>

Nader Filho A., Ferreira L.M., Amaral L.A., Rossi Junior O.D. \& Oliveira R.P. 2007. Produção de enterotoxinas e da toxina da síndrome do choque tóxico por cepas de Staphylococcus aureus isolados de mastite bovina. Arq. Bras. Med. Vet. Zootec. 59(5):1316-1318. <http://dx.doi.org/10.1590/S010209352007000500032>

NMC 1999. Laboratory Handbook on Bovine Mastitis. National Mastitis Council, Madison, WI. 222p.
Oliveira C.M.C., Sousa M.G.S., Silva N.S., Mendonça C.L., Silveira J.A.S., Oaigen R.P., Andrade S.J.T. \& Barbosa J.D. 2011. Prevalência e etiologia da mastite bovina na bacia leiteira de Rondon do Pará, estado do Pará. Pesq. Vet. Bras. 31(2):104-110.<http://dx.doi.org/10.1590/S0100-736X2011000200002>

Piepers S., De Meulemeester K., De Aart L., Opsomer G., Barkema H.W. \& Vliegher S. 2007. Prevalence and distribution of mastitis pathogens in subclinically infected dairy cows in Flanders, Belgium. J. Dairy Res. 74(4):478-483. <http://dx.doi.org/10.1017/S0022029907002841><PMid:17931457>

Pimentel F.E., Dias R.S. \& Carmo L.S. 2002. Presença de Staphylococcus sp enterotoxigênico e de enterotoxinas em queijo ralado. Revta Inst. Laticínios Cândido Tostes, Juiz de Fora, 57:227-229.

Pinchuk I.V., Beswick E.J. \& Reyes V.E. 2010. Staphylococcal enterotoxins. Toxins 2(8):2177-2197. <http://dx.doi.org/10.3390/toxins2082177> $<$ PMid:22069679>

Quinn P.J., Carter M.E., Markey B., Donnelly W.J. \& Leonard F.C. 2005. Actinomicetos, p.74-82. In: Ibid. (Eds), Microbiologia Veterinária e Doenças Infecciosas. Artmed, Porto Alegre.

Rabello R.F., Souza C.R.V.M., Duarte R.S.R., Lopes M.M., Teixeira L.M. \& Castro A.C.D. 2005. Characterization of Staphylococcus aureus isolates recovered from bovine mastitis in Rio de Janeiro, Brazil. J. Dairy Sci. 88(9):3211-3219. <http://dx.doi.org/10.3168/jds.S0022-0302(05)73004-6><PMid:16107411>

Radostits O.M., Gay C.C., Hinchcliff K.W. \& Constable P.D. 2007. Veterinary Medicine. 10th ed. Saunders Elsevier, Philadelphia. 2156p.

Rall V.L.M., Miranda E.S., Castilho I.G., Camargo C.H., Langoni H., Guimarães F.F., Araújo Júnior J.P. \& Fernandes Júnior A. 2014. Diversity of Staphylococcus species and prevalence of enterotoxin genes isolated from milk of healthy cows and cows with subclinical mastites. J. Dairy Sci. 97(2):829-837. <http://dx.doi.org/10.3168/jds.2013-7226> <PMid:24359821>

Ribeiro M.G., Geraldo J.S., Langoni H., Lara G.H.B., Siqueira A.K., Salerno T. \& Fernandes M.C. 2009. Microrganismos patogênicos, celularidade e resíduos de antimicrobianos no leite produzido no sistema orgânico. Pesq. Vet. Bras. 29(1):52-58. <http://dx.doi.org/10.1590/S0100-736X2009000100008>

Roberson J.R., Fox L.K., Hancock D.D., Gay J.M. \& Besser T.E. 1996. Prevalence of coagulase-positive staphylococci, other than Staphylococcus aureus, in bovine mastitis. Am. J. Vet. Res. 57(1):54-58. <PMid:8720238>

Schalm O.W. \& Noorlander D.O. 1957. Experimental and observation leading to development of California Mastitis Test. J. Am. Vet. Med. Assoc. 139(5):199-204.<PMid:13416088>

Silva J.A. \& Tsukamoto R.Y. 2001. A modernização da pecuária leiteira e a exclusão do pequeno produtor. Geografia, Londrina, 10(2):147-162.

Silva N.C.C., Guimarães F.F., Manzi M.P., Gómez-Sanz E., Gómez P., Araújo-Júnior J.P., Langoni H., Rall V.L. \& Torres C. 2014. Characterization of methicillinresistant coagulase-negative staphylococci in milk from cows with mastitis in Brazil. Antonie van Leeuwenhoek 106(2):227-233. <http://dx.doi. org/10.1007/s10482-014-0185-5><PMid:24817534>

Siqueira A.K. 2011. Indicadores de qualidade, pesquisa de marcadores de virulência e multirresistência aos antimicrobianos em estirpes de Staphylococcus spp. em leite de origem bovina produzido no sistema orgânico. Doctoral Dissertation, Faculdade de Medicina Veterinária e Zootecnia, Universidade Estadual Paulista, Botucatu, SP. 155p.

Soriano J.M., Font G., Moltó J.C. \& Mañes J. 2002. Enterotoxigenic staphylococci and their toxins in restaurant foods. Trends Food Sci. Technol. 13(2):60-67. <http://dx.doi.org/10.1016/S0924-2244(02)00030-4>

Souza G.N., Brito J.R.F., Moreira E.C., Brito M.A.V.P. \& Silva M.V.G.B. 2009. Variação da contagem de células somáticas em vacas leiteiras de acordo com patógenos da mastite. Arq. Bras. Med. Vet. Zootec. 61(5):1015-1020. <http://dx.doi.org/10.1590/S0102-09352009000500001>

Tanabe T., Sato H., Sato H., Watanabe K., Hirano M., Hirose K., Kurokawa S., Nakano K., Saito H. \& Maehara N. 1996. Correlation between occurrence of exudative epidermitis and exfoliative toxin-producing ability of Staphylococcus 
hyicus. Vet. Microbiol. 48(1/2):9-17. <http://dx.doi.org/10.1016/03781135(95)00144-1><PMid:8701581>

Tavares W. 2000. Bactérias gram-positivas problemas: resistência do estafilococo, do enterococo e do pneumococo aos antimicrobianos. Revta Soc. Bras. Med. Trop. 33(3):281-301.<http://dx.doi.org/10.1590/S003786822000000300008> <PMid:10967598>

Trabulsi L.R., Alterthun F., Gompertz O.F. \& Candeias J.A.N. 1999. Microbiologia. $3^{\mathrm{a}}$ ed. Atheneu, São Paulo. 586p.

Vintov J., Aarestrup F.M., Zinn C.E. \& Olsen J.E. 2003. Association between phage types and antimicrobial resistance among bovine Staphylococcus aureus from 10 countries. Vet. Microbiol. 95(1/2):133-147.<http://dx.doi. org/10.1016/S0378-1135(03)00156-1><PMid:12860083>

Zafalon L.F., Amaral L.A., Nader Filho A. \& Oliveira J.V. 1999. Influência de bactérias do gênero Corynebacterium e estafilococos coagulase positivos e negativos sobre a contagem de células somáticas e a produção láctea de quartos mamários com mastite subclínica. Revta Napgama, São Paulo, 6:4-6.

Zoli J.A., Negrete I.R.A. \& Oliveira T.C.R.M. 2002. Avaliação da contaminação por S. aureus e Salmonella spp. De maionese de batata comercializada em Londrina, PR. Revta Hig. Aliment. 16(95):62-70. 